\title{
Historical setting and neuropathology of lathyrism: Insights from the neglected 1944 report by Oliveras de la Riva
}

\author{
Santiago Giménez-Roldán, F. Morales-Asín, Isidre Ferrer, and Peter S. Spencer
}

\section{QUERY SHEET}

This page lists questions we have about your paper. The numbers displayed at left are hyperlinked to the location of the query in your paper.

The title and author names are listed on this sheet as they will be published, both on your paper and on the Table of Contents. Please review and ensure the information is correct and advise us if any changes need to be made. In addition, please review your paper as a whole for typographical and essential corrections.

Your PDF proof has been enabled so that you can comment on the proof directly using Adobe Acrobat. For further information on marking corrections using Acrobat, please visit http://journalauthors.tandf.co.uk/production/acrobat.asp; https://authorservices.taylorandfrancis.com/how-to-correct-proofs-with-adobe/

The CrossRef database (www.crossref.org/) has been used to validate the references. Changes resulting from mismatches are tracked in red font.

\section{AUTHOR QUERIES}

Q1 In References, Grandjean is dated 1895. Which year is correct?

Q2 In References, Selye is dated 1957. Which year is correct?

Q3 Please add Barrows 1974 to the Reference list.

Q4 In Refs. Buchanan is dated 1927. Which year is correct?

Q5 Please add The Indian Express (2016) to the References.

Q6 In References you list Kozhevnikov 1883 and 1885, but no 1893. Please provide the 1893 reference.

Q7 What is the 60-page monograph you are referring to? Should Kozhevnikov 1893 be cited at the end of this sentence?

Q8 Please add ABC journal to the References.

Q9 In References, Huertas is dated 2006. Which year is correct?

Q10 Please add La Vanguardia (1938) to the Refs.

Q11 In Refs., Massot i Gimeno is dated 1942. Which year is correct?

Q12 Please add Jimenez Casado (1993) to the Refs.

Q13 Please add is Jiménez Díaz et al. (1941) to the References.

Q14 Please add Giménez-Roldán \& Spencer (in preparation) to the Reference list. 
Q15 Please add Llorens (2016) to the Refs.

Q16 What do you mean by “...but he was ceased a few days leter at Cajal Institute”? Please clarify.

Q17 Please check spelling: Author name Mishra spelled Misra in reference list. Which is correct?

Q18 Please check spelling. The author Paissos is spelled Paissios later. Which is correct?

Q19 Per earlier query, please check spelling: Paissios or Paissos?

Q20 The figure supplied for Figure 3 does not appear to be the correct figure for this legend. Please check and provide the correct legend or figure accordingly.

Q21 In Figure 4, the page numbers appear to be pp. 317 and 316. Please check and revise accordingly.

Q22 Do you have the page number of the block quote that begins "Glial changes depend on time elapsed since the injury..."?

Q23 In Refs, Hawkins et al. is dated 2016. Which year is correct?

Q24 For this Moya 1967 citation, should it be 1967a or 1967b?

Q25 Per earlier query, check spelling: Paissos or Paissios?

Q26 Please add Tshala-Katumbay et al. (2011) to the References.

Q27 Per earlier query, check spelling: Paissios or Paissos?

Q28 Moya et al. 1967a or 1967b?

Q29 Please provide the Buchanan 1897 reference.

Q30 For the Bruyn and Poser 2003 chapter, please list editor(s) of the book.

Q31 Desparanches 1829 is not cited in text. Please add an in-text citation or delete.

Q32 Freemon 1992 not cited in text. Please cite or delete.

Q33 Gallego 1979 not cited in text. Cite or delete. If kept, please provide page number(s) if available.

Q34 González et al. 2014 not cited in text. Please add an in-text citation or delete from list.

Q35 Please give volume number for Massot i Gimeno 1942.

Q36 Please check spelling: Mishra or Misra?

Q37 Rossolimo 1891 not cited in text. Cite or delete.

Q38 Shterenshi and Vaiman 2007 not cited in text. Cite or delete.

Q39 Spencer et al 1986 not cited in text. Cite or delete.

Q40 Stockman 1929 not cited in text. Cite or delete. 


\title{
Historical setting and neuropathology of lathyrism: Insights from the neglected 1944 report by Oliveras de la Riva
}

\author{
Santiago Giménez-Roldán ${ }^{\mathrm{a}}$, F. Morales-Asín ${ }^{\mathrm{b}}$, Isidre Ferrer (1) ${ }^{c}$ and Peter S. Spencer ${ }^{d}$ \\ ${ }^{a}$ Department of Neurology, Hospital General Universitario Gregorio Marañón, Madrid, Spain; ${ }^{\text {bDepartment of }}$ \\ Neurology, Hospital Clínico Universitario Lozano Blesa, Faculty of Medicine, Zaragoza, Spain; 'Department of \\ Pathology and Experimental Therapeutics, University of Barcelona, campus Bellvitge, CIBERNED, Hospitalet de \\ Llobregat, Barcelona, Spain; ${ }^{d}$ Department of Neurology, School of Medicine, and Oregon Institute of \\ Occupational Health Sciences, Oregon Health \& Science University, Portland, Oregon, USA
}

\begin{abstract}
Lathyrism is a central motor system disorder recognized since antiquity resulting from prolonged dietary dependence on the grasspea (Lathyrus sativus). The neuropathology underlying the characteristic spastic paraparesis of lathyrism is sketchy. Described here is a landmark but littleknown Spanish-language neuropathological study of two patients with lathyrism of recent onset. Due to erroneous interpretations of Filimonov's influential work in 1926, it was assumed that spastic paraparesis of lathyrism was explained by destruction of Betz's pyramidal cells in the motor cortex. Contrary to present understanding, Betz cells and anterior horn cells were preserved, and pathological findings dominated by myelin loss were largely limited to pyramidal tracts in the lumbar cord. Thickening of the adventitia of capillaries and arterioles, together with proliferation of perivascular astrocytes, was found along the length of the spinal cord. Oliveras de la Riva proposed that the segmental spinal pathology arose because distal regions of elongate pyramidal tract $i x \cup \mid \mathrm{s}$ are distant from their trophic center in the motor cortex, a concept $r \quad r$ from the current distal axonopathy concept of lathyrism. In addition, we review the historical circumstances of Filimonov's work in Rus . $i$, a summary of the epidemic of lathyrism in Spain following its civil,$\overline{\text { rr }}$ 1936-1939), and some historical aspects of Cajal Institute in Madrid, where Oliveras de la Riva's work was carried out under supervision of Fernando de Castro, one of Cajal's favorite students.
\end{abstract}

\section{KEYWORDS}

Betz cells; Filimonov; history; lathyrism; neuropathology; Oliveras de la Riva De Castro; spinal blood vessels

\section{Lathyrism: A neurotoxic disease of the past and the future}

Lathyrism is a nutritional neurotoxic upper motor neuron disease characterized by varying degrees of irreversible spastic paraparesis. The caus - excessive and prolonged food dependency on the seed of the grasspea (Lathyrus $s \overline{\bar{t}}$ us, LS), a leguminous plant containing the excitotoxic amino acid $\beta$-N-oxalyl- $\alpha, \beta$-diaminopropionic acid (L- $\beta$ ODAP), an agonist of the glutamate $\alpha$-amino-3-hydroxy-5-methyl-4-isoxazolepropionic acid (AMPA-type) receptor (Barrow, Simpson, \& Miller, 1974; Spencer, 1995).

One of the oldest known neurotoxic diseases (Bruyn \& Poser, 2003), the dis $\overline{\bar{r}} d$ er was known to ancient Hindus, to Hippocrates (460-377 BC), Pliny the Elder (23-79 AD), Pedanius Dioskurides (50 AD), and Galen (130-210 AD). In 1671, Duke George of 
Württemberg banned consumption of grasspea because of its ability to "paralyze" the legs. In 1690, the Italian physician Ramazzini described an outbreak of the disease in Modena; and another Italian, Cantani (1873), coined the name "latirismo" to describe the condition. Epidemics of lathyrism occurred throughout the nineteenth and twentieth centuries during famines related to droughts and armed conflicts, with hundreds of thousands of people affected in Africa, Asia, and Europe (Sleeman, 1844; Cantani, 1873; San Martín, 1873; Bourlier, 1882; Proust, 1883; Grandjean, 1885; Selye, 1917; Stockman, 1917; Acton, 1922; Carrot and Coulmel, 1946; Kessler, 1947; Lebon \& Choussat, 1948; Jiménez Díaz et al., 1950; Rodríguez Arias, 1950; Barrows, 1974; Haque et al., 1996; Haileyesus et al., 1999; Woldemanuel et al., 2012; Giménez-Roldán \& Spencer, 2016).

In India, the consumption of grasspea, or khesari-dal, caused extensive epidemics in the early-twentieth century (Buchanan, 1896), but cultivation of les: toxic seeds in the 1990s, methods to eliminate L- $\beta$-ODAP (also known as beta-N-oxalyramino-L-alanine, L-BOAA), and favorable socioeconomic changes have reportedly led to its virtual disappearance (Miles, 2005; Wadia, 2005; Singh \& Rao, 2013). In fact, a 55-year-old ban on consuming khesari-dal was recently lifted in India (The Indian Express, January 19, 2016). This is not the case in some countries in Africa and Asia, where L. sativus tolerates droughts, floods, and high soil salinity, which cause other crops to fail, thereby requiring people to shift increasingly to grasspea for nutritional subsistence during extreme environmental conditions (Kumar et al., 2011). Given the forecast of rapid population growth in Africa and climate changes that favor survival of environmentally tolerant plants, notably grasspea, lathyrism should also be considered a potential future health threat (Enneking, 2011).

The purpose of this article is to describe a publication so far neglected on the neuropathology of lathyrism. It was carried out on two patients who died shortly after disease onset by neurologist Carlos Oliveras de la Riva (1914-2007) during the extensive post-Civil War epidemics in Spain (Oliveras de la Riva, 1944). So far, the only study available has been published by the Russian neuropathologist Ivan Nikolaevisch Filir ov (1890-1966), often wrongly quoted as evidence of damage to pyramidal Betz cells at mary motor cortex of the brain (Bruyn \& Posner, 2003).

\section{A brief history of lathyrism in Spain}

The earliest evidence of Lathyrus gende $=$ the prehistoric Iberian Peninsula comes from early and middle Neolithic cave sites, where a large quantity of charred seeds presumably used for food has been found (Peña-Chocarro \& Chapata-Peña, 1999). During the Madrid famine following var oleonic troop invasion in 1808, an engraving of the celebrated painter Francisco de Goya entitled Gracias a la almorta (Thanks to Grasspea) shows a group of people eating grasspea gruel from a large pan. A woman approaches by crawling on the ground, suggesting she is suffering from advanced lathyrism (Dwivedi \& Prasad, 1964; see Figure 1). Traditionally, grasspea has been used for food in Spain for centuries, particularly among the rural population of Castilian provinces, mainly Toledo, Cuenca, and Ciudad Real in the central part of the country, a region subject to prolonged seasonal droughts (Pascual Madoz, 1846-1850). Cultivated in small family plots, it is usually eaten, even today, as gachas, a gruel cooked with oil and seasoned with pieces of pork belly, garlic, and salt. Grasspea complemented the daily diet, especially among farm workers during the harsh winters, thanks to its pleasant taste, protein-rich content, and excellent caloric intake. 


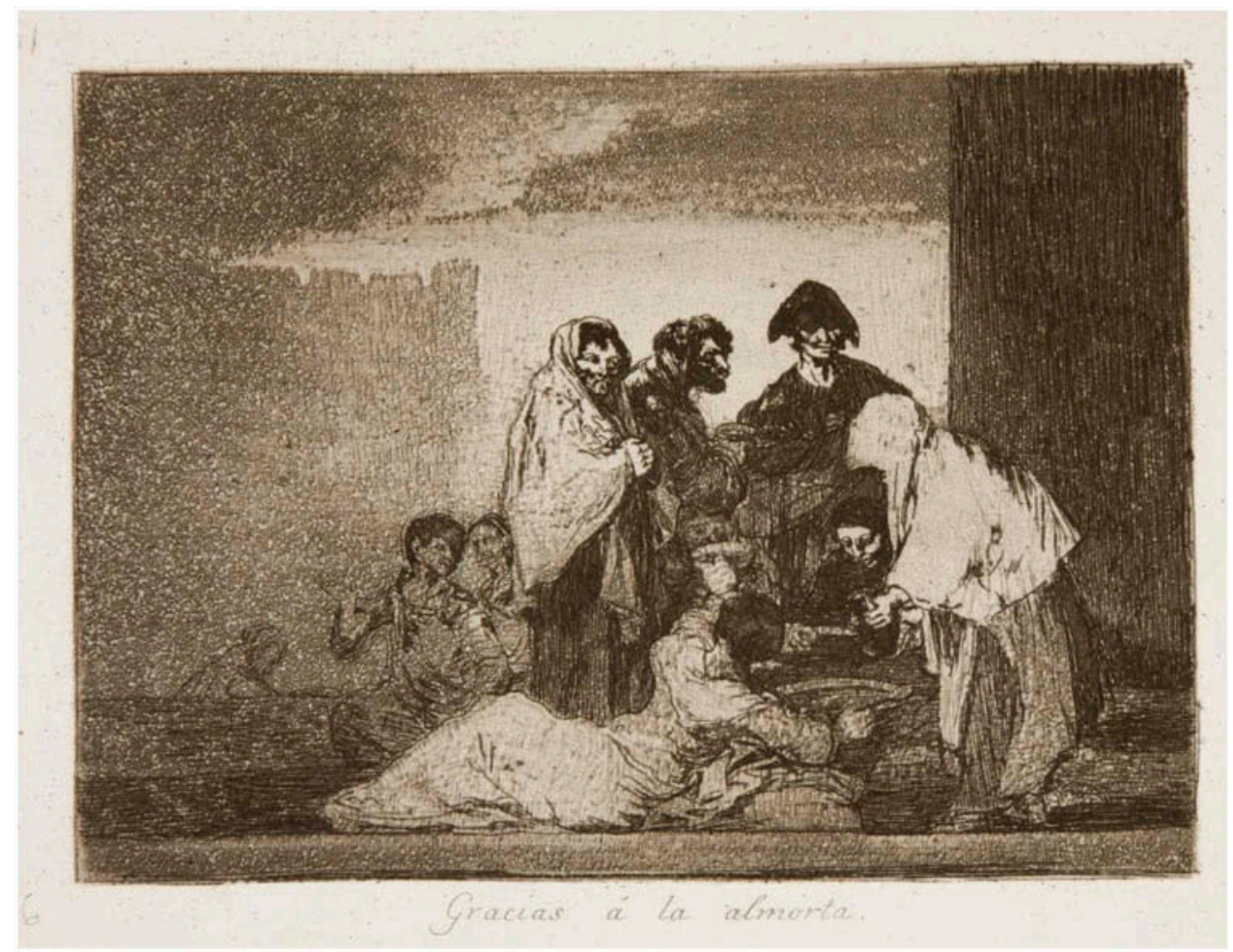

Figure 1. Francisco de Goya's engraving entitled Gracias a la almorta (Thanks to grasspea). In The Disasters of War (1810-1814). Image from Goya Foundation of Aragón.

The first scientific communication on lathyrism in Spain was undertaken in Real Academia Nacional de Medicina (RANM), in Madrid, by Enrique Fernandez Sanz (1872-1950), an internal medicine doctor with excellent neurological training. On June 12, 1916, he reported two brothers, aged 19 and 26 years, who had developed fatigue and leg stiffness after feeding for three months on grasspeas (Fernandez Sanz, 1916). Shortly thereafter he received a letter from Dr. Félix Serrano Sanz, a physician from Cifuentes, Guadalajara province, a town close to Azañón, reminding him of the epidemic that Alejandro San Martín (1847-1908) had extensively investigated in 1873 for which he coined the name Azañón's disease when lathyrism had no better name (Cantani, 1873; Giménez-Roldán \& Spencer 2016). In this regard, a second communication by Fernandez Sanz (1918) dealt with the important contribution of San Martin (Fernandez Sanz, 1917). Likewise, the veterinarian Dalmacio Garcia Izcara (1859-1927) contributed on animal lathyrism, according to his experience (Garcia Izcara, 1918).

\section{The history of lathyrism in Russia: Kozhevnikov, Rossolimo, and Filimonov}

The first Russian author to investigate lathyrism was Alexei Yakovlevich Kozhevnikov 100

(1835-1902), after an extensive epidemic during 1881-1882 in the collectivized labor fields of Saratov, on the banks of Volga River (Kozhevnikov, 1893). According to some authors, it caused 140 cases (Valko \& Bassetti, 2006), although due to isolation of the country and 
unavoidable language barriers, few details from Kozhevnikov's 60-page monograph are available at the moment. Kozhevnikov is considered "father of Russian neurology" (Grashchenkov, 1960; Vein, 2007) and is known mainly for his description of epilepsia partialis continua, a particular form of persistent status epilepticus with simple motor focal seizures of varied aetiology, from stroke to Rasmussen encephalitis and springsummer Russian encephalitis (Bejr-kasem et al., 2016; Mameniskiené \& Wolf, 2017).

Less well known are Kozhevnikov's neurohistological and neuropathological studies on pyramidal cells at primary motor cortex and their projection toward the spinal cord. His description on pyramidal cell loss in amyotrophic lateral sclerosis was of particular clinical importance, as degeneration could be traced up to levels above the spinal cord and because it proved the origin of the pyramidal tract confined to the precentral gyrus (Kozhevnikov, 1883, 1885; Valko \& Bassetti, 2006).

Kozhevnikov's reports nearly overlapped those of the Ukrainian Vladimir Alexenwitsch Betz (1834-1894) who in 1874 and 1875 developed a novel concept defining two cortical areas, motor and sensory, the fissure of Rolando as a border between the anterior part of the cortex as the seat of "giant" pyramidal cells (according to the term applied by him) in layer V, and the posterior area (including the temporal lobe), where "nuclear" layers would predominate with sensory properties (Kushchayev et al., 2012). It is likely that Kozhevnikov wondered about the neuropathology in his Saratov patients, but the response would take more than 30 years to arrive, at least partially. The publication in 1926 by Russian neuropathologist Ivan Nikolaevisch Filimonov (1890-1966; see Filimonov, 1926) has been wrongly considered the paper that most firmly established the neuropathology of lathyrism (Bruyn \& Poser, 2003, pp 89-108), despite words of caution (Spencer et al., 1984).

Filimonov published his work in 1926 as a member of Aus der Nervenklinik au der Univrsität zur Moscow, but significantly signed as an "external lecturer." Although Professor Grigorii Ivanovich Rossolimo (1860-1928) headed the publication, it seems unlikely he would beable to contribute to the publication, as he was disabled from a stroke he suffered three years before (Satran, 2007). As a Kozhevnikov disciple, Rossolimo, "an imaginative, capable and clinically dedicated man," was entrusted in the direction of the service after Kozhevnikov's death in 1917, and was probably involved in patient Merkus Gal.'s extensive, long-term follow up. He had worked on anatomy and physiology of the nervous system as a young doctor, but thereafter he devoted himself to clinical neurology, describing numerous reflexes, particularly "variants" of Babinski sign (Rossolimo, 1902). University unrest led him to resign from his university position, after which he founded a small private clinic dedicated to child neuropsychiatry, his late vocation (Satran, 2007). His brain was one of the 14 "geniuses" collected by the Vogts in the "Pantheon of Brains" (Richter, 2007; Vein \& Maat-Schieman, 2008).

The "Cultural Revolution" in the Soviet Union from 1928 to 1932 meant a traumatic time for all fields of culture, including the neurosciences. In 1927, Joseph Stalin seized power, installing a regime of political repression, aggressive economic planning, and forced collectivization of agriculture (Bushkovitch, 2012, pp. 340-341). Filimonov's affinity with the new regime (and perhaps his 1926 publication) seems to have promoted his scientific career, particularly after Cécile and Oskar Vogt were appointed directors of the Moscow Brain Research Institute to discuss "whether their cytoarchitectonic investigations could provide information on the material substrate of Lenin's genius" (Richter, 2007). Filimonov was one of the neuropathologists who joined the Vogts. After that, he became deputy director of sciences 
and a highly respected member of the USSR Academy of Medical Sciences (1927-1958; see http://bigmed.info/index.php/FILIMONOV_Ivan_Nikolaevich for more information).

\section{Merkul Gal., a key lathyrism patient}

Patient Merkul Gal., on whom Filimonov carried out his postmortem study, developed lathyrism in the collectivized labor fields of Saratov (1881-1882) after high and prolonrad consumption of Tschina (grasspea), which a botanist identified as the seed of L. sa He was taken to Moscow, an 858-kilometer trip, to be admitted at the Nervenklinik in January 1893 under the care of Kozhevnikov. Except for the disappearance of tremor in the upper limbs and urinary urgency as early symptoms, the patient's disability did not change over 30 years of post-injury follow up. The patient was forced to use two sticks to walk, had severe spastic paraparesis, his sensation was normal, and there was no muscular atrophy. He died in 1923 at the age 53 due to fulminant lymphoid leukemia.

Filimonov (1926) was well aware of Cantani's publication in 1873, the author who had coined the term lathyrism, but he ignored the extensive epidemic of lathyrism in central Spain reported in 1873 by Alejandro San Martín. Considering the severe, "pure" spastic paraparesis of lathyrism, Filimonov paid special attention to giant pyramidal cells within the fifth layer of the primary motor cortex, whose histology and function had been described by Alexei Y. Kozhevnikov (Valko \& Bassetti, 2006) and Vladimir A. Betz (Kushchayev et al., 2012). Filimonov was convinced of the relevance of his work, "considering the lack of anatomical material to date," and was concerned about "the absence of pathological data at the beginning of the disease." Yet, Filimonov's findings regarding Betz's pyramidal cells in the motor cortex were disappointing: "The Betz cells in relation to the norm are in very little quantity, sometimes one or two in a whole preparation ... where in lamina magnopyramidalis are unrecognizable." Loss of Betz cells was marked "in the paracentral lobe and an area anterior to the central gyrus" (Filimonov, 1926, p. 85), possibly meaning the medial surface of the hemisphere and the gyrus close to the central sulcus. Surviving cells were deformed and shrunken, often with wide pericellular spaces. Key findings included "a large number of lymphomatous clusters in all areas of the brain, such as cerebral cortex, basal ganglia, cerebellum, and medulla oblongata," but not so in the spinal cord, as shown by van Guieson and thionine staining.

Regarding pyramidal tract changes, he asked himself: "To what extent leukemia could be responsible for fasciculi lesions noticed at the spinal cord?" Nevertheless, he concluded it might be "a genuine feature of lathyrism considering their chronicity." The original description reveals a peculiar distribution of pyramidal tract changes in the lateral columns of the spinal cord. "Pallor in the C6-C7 segment was evident, but appeared more intense in C8, being maximal between T2 and T10 segments" (Filimonov, 1926, pp. 86-88). In accord with present understanding, Betz cells and anterior horn cells were preserved, and pathological findings dominated by myelin loss were largely limited to pyramidal tracts in the lumbar spinal cord. Filimonov noted, "More distally, in lumbar segments, the [microscopic] degenerative field gradually decreases, limited to the periphery of lateral columns. Degeneration runs upwards to reach the medulla oblongata, pons and the internal capsule, albeit less in intensity" (1926, p. 314).

He underlined diffuse changes of blood vessels, especially in the upper thoracic segments of the lateral columns and grey commissure. "In relation to vessel changes, there are many areas of focal, decreased tissue thickness that were more evident in the grey matter and lateral 
columns" (Filimonov, 1926, p. 314). Staining with the Snessaref method revealed marked proliferation of glia in such areas.

To summarize, the status of Betz cells in lathyrism remained an open question. Filimonov was well aware of the need to study cases with a much shorter disease course, as well as the devastating effects of massive leukemic infiltrates in cerebral cortex in his patient.

\section{Feeding disorders related to the Spanish Civil War (1936-1939): Alimentary deficiency vs. lathyrism}

The Spanish Civil War (1936-1939) and the long postwar years were times of widespread food shortages (Carr, 1967; Thomas, 1977; Del Arco Blanco, 2006; Culebras, 2014), yet nutritional deficiency disorders and lathyrism did not coincide in time or location because of different local circumstances. Barely four months after the war started, Madrid, the country's capital, was besieged, except for a small corridor to the Mediterranean. Food distribution in Madrid was chaotic, and each family was forced to fend for itself ( $A B C$ journal, September 15, 1936). The Falangist organization "Social Assistance" daily fed half-a-million children in 3,000 dining halls across Spain (Lafuente, 1999, pp. 142). Caloric intake barely reached half of the minimum requirements per inhabitant, proteins were almost entirely of vegetable origin, and severe vitamin deficiencies were detected in the population, in particular group B vitamins (Jiménez Garcia \& Grande Covián, 1940). From 1940 on, an official “individual ration card” procured 80 grams of bread per day and 100 grams meat per week (Lafuente, 1999, p. 32). In a context of generalized famine, the shortage involved mainly foods of animal origin, which was followed by multivitamin deficiency disorders, especially related to group B vitamins (Jiménez García \& Grande Covián, 1940). Painful sensory neuropathy (Peraita, 1946; Del Cura \& Huertas, 2007; Huertas \& Del Cura, 2010), sensory ataxic neuropathy (Peraita, 1949), and pellagra psychosis (Llopis, 1943, Huertas, 2007, pp. 293-297), in addition to hunger oedema, scurvy, and glossitis, were conditions commonly observed. In summary, deficiency alimentary disorders focused on Madrid population during the war and early postwar years.

The Spanish epidemic of lathyrism was a postwar disease, with a peak incidence between 1941 and 1942, although new cases were observed up to 1949 (Jiménez Díaz et al., 1950). Despite ne interest shown by the new authorities, reports suggested around a thousand victims in the whole country (Camy Sánchez-Cañete, 1945). Scarcity and poverty continued during postwar years throughout the country, but massive and continued intake of grasspeas (variedly known as almortas, guixes, muelas, and titos) was localized in specific areas. Such was the case in Catalonia, where in 1941 neurosurgeon Emilio Ley and neurologist Carlos Oliveras de la Riva were alerted to the ongoing epidemics based on 19 patients residing in the industrial belt of Barcelona, mostly poorly paid immigrants from different Spanish provinces (Ley and Oliveras de la $\mathrm{R}^{\text {van }}$, 1941). After massive importation, grasspea became much cheaper than chickpea (Cicer atinum), the nonneurotoxic legume that hitherto had represented the staple food for low-income people (.80 vs. 3.20 pesetas per kilogram, according to the newspaper La Vanguardia, October 8, 1938). An extensive survey in Barcelona province carried out by Oliveras de la Riva found 156 patients, as he wrote in his unpublished doctoral thesis, according to a typed copy kept in the Marques de Valdecilla library in Madrid (Oliveras de la Riva, 1941).

Ignasi De Gispert Cruz (1903-1984) was a Catalan neurologist who achieved considerable experience in Santa Creu Hospital, Barcelona,-in lathyrism patients, mainly from the 
towns of Esparreguera, Olesa de Montserrat, Igualada, and other places (De Gispert, 1976, p. 149). His study on infantile lathyrism in four children aged 4 to 9 years was the first to specifically address this age group. Although the clinical picture was not different from adults, children developed a severe paraparesis shortly after a brief exposure to grasspeas, as short as following 15 meals in the youngest one, whereas the rest of the family members, including brothers and sisters, escaped. Authors concluded that young children might have an unusual sensitivity to the yet-unknown neurotoxin (Sala Ginabreda \& De Gispert Cruz, 1943). In other Catalonia provinces, lathyrism was observed exceptionally (Massot i Gimeno, 1944).

A second and extensive focus of postwar lathyrism took place in rural Castile, an extensive region in central Spain (currently divided into two communities, Castilla-La Mancha and Castilla-León). Farmers managed to produce food in small plots for family consumption during the war years. Thereafter, shortage of hands to work in the fields, persistent drought, and poor cereal and potato harvests forced poor peasants to rely on grasspea as a staple food. Jiménez Díaz and colleagues (1943) collected data on 549 patients in 1943, mostly from Castilian provinces.

Carlos Jiménez Díaz (1898-1967) is considered the father of modern medicine in Spain. $\mathrm{He}$ and his coworkers produced a large number of publications on lathyrism for nine years, from clinical and nutritional aspects to epidemiology and experimental studies. In addition to field studies, laboratory research was carried out at Medical Research Institute, a prestigious hospital founded by Jiménez Díaz himself that remains today as the Jiménez Díaz Foundation-Clínica de la Concepción in Madrid (Jiménez Casado, 1993).

In 1941, Jiménez Díaz organized an expedition to the town of Consuegra, in the province of Toledo, where alarming news came about dozens of people developing a paralytic illness, supposedly previously unknown in the country (López Ibor \& Peraita, 1941). Patients were consuming an average of 500 grams per day of grasspeas but, unlike what has been observed in Madrid during the war years, these patients looked well-nourished, in keeping with the high protein content of the legume (Jiménez Díaz et al., 1941). The town of Consuegra became a historical focus in the research of lathyrism, and has been revisited repeatedly by the present authors for 30 to 40 years (Moya et al., 1967a, 1967b; Hugon et al., 1990, 1993; Giménez-Rold án et al., 1994; Crone et al., 2006, 2007). The epidemic of postwar lathyrism in Spain has been probably the most extensively investigated in history. Sixty-eight papers dealing with the epidemic were recently recovered, a wealth of information that has gone largely neglected due to isolation of the country at the time and language barriers (Giménez-Roldán \& Spencer, in Q14 preparation). Only a few, incomplete reviews on postwar lathyrism are available today in Spanish and Catalan (Del Cura \& Huertas, 2009; Fasanella i Seligrat, 2011; Balcells, 2017), as well as two brief publications in English (Culebras, 1979; Llorens, 2016).

\section{Neuropathology of lathyrism: The role of Carlos Oliveras de la Riva (1914-2007) and Fernando De Castro (1896-1967)}

When Carlos Oliveras de la Riva, a 27-year-old Catalan neurologist, arrived in Madrid in 1941, he was no doubt the doctor with the most extensive experience in lathyrism in the country (see Figure 2a). As mentioned, he had made the first communication in Spain on the ongoing epidemic in progress on 19 patients admitted to the Municipal Neurological Institute (MNI) in 1941 (Ley and Oliveras de la Riva, 1941). In that same year, he undertook 

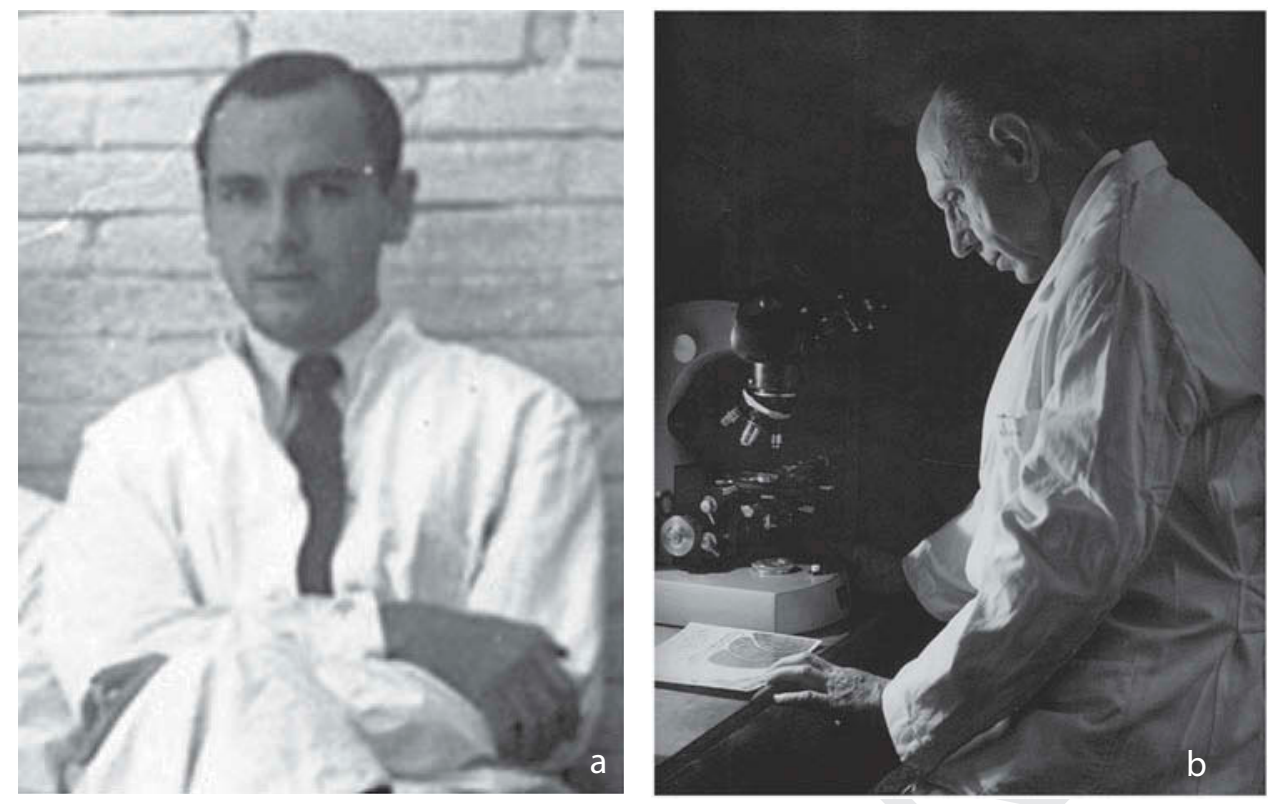

Figure 2. Spanish investigators: (a) Carlos Oliveras de la Riva (1914-2007), neurologist and neuropathologist, circa 1944; and (B) neurohistologist Fernando De Castro Rodríguez (1896-1966), circa 1960.

an epidemiological survey in the province of Barcelona (Oliveras de la Riva, 1941). The MNI was a 110-bed neurological hospital in Barcelona, with several neurological subspecialties and an average of a thousand annual admissions (Rodríguez Arias, 1969; Solé-Llenas, 1998). Carlos Oliveras was accepted at Cajal Institute as an honorary fellow-that is, with no financial support. Presumably it did not represent a problem to him as he came from a wealthy family, with strong financial interests in the textile industry and even ownership of the Spanish Premier Reial Club Deportiu Espanyol de Barcelona (Balcells, 2017).

Well aware of the interest in having anatomical specimens from two patients with lathyrism of recent onset, Oliveras de la Riva's trip to Madrid was promoted by Belarmino Rodríguez Arias (1895-1997), the director of the MNI and one of the founders of the Spanish Society of Neurology. Oliveras de la Riva gratefully dedicated to Don Belarmino a reprint of his paper (Oliveras de la Riva, 1944), kept in the historical museum of the Spanish Society of Neurology.

The decision to ask Professor Fernando de Castro Rodríguez (1896-1967) to supervise the neuropathological study at the Cajal Institute in Madrid was afortunate decision, albeit under deplorable circumstances (Figure 2b). The year 1941 is still remembered locally as "the year of hunger," and also was characterized by ferocious repression. De Castro had remained in Madrid throughout the war under German bombing, taking care of the Cajal Institute and sharing with his dogs his meager lunch while continuing his studies on the innervation and functions of the carotid body (Glomus caroticum). At the end of the war he was dispossessed of his chair as professor of histology, allowing him to continue as a research assistant with the paltry salary of 250 pesetas per month $(€ 41,5)$. Unable even to feed his wife and son, he was forced to work as an assistant to surgeon Salas de Pablo. He had been working with Cajal since his second year on the faculty and had mastered the staining techniques of the Spanish School 
of Neurohistology. Cajal entrusted his teaching to the many foreign visitors and students who came to the Institute. Finally, they jointly published a book on the subject in 1933, when the maestro only had one year to live (Ramón y Cajal \& De Castro, 1933).

In a series of works between 1926 and 1929, De Castro established that the carotid body is a sensitive receptor (chemoreceptor) able to detect chemical changes in the composition of blood. Regrettably, given the dramatic circumstances of the country and without the necessary supports, he was not proposed for the Nobel Prize. Finally, it was Corneille Heymans, his close friend, who won the Nobel Prize in Physiology and Medicine in 1938 (De Castro, 2009). "Not reaching the Nobel Prize left a mark on Castro's spirit," commented one of his closest collaborators (Aguirre De Viani, 2002, pp 121-135). To some extent, he was fortunate to be allowed to remain in Madrid, the city where he was born, considering that the vast majority of Cajal's disciples were condemned to exile or ostracism (Giménez-Roldán, 2015).

Back in Barcelona, Oliveras de la Riva continued to combine clinical neurology and pathological diagnosis of brain tumors, which he had also learned in Madrid. He became president of the Spanish Society of Neurology and chief professor of this specialty at Hospital Clinir in Barcelona. Fernando de Castro was replaced in his chair in March 1951, but was ceas few days later at Cajal Institute (Aguirre de Viani, 2002). At present, Cajal Institute of Madrid (www.cajal.csic.es) is a high-level biological research center with more than 100 years of history and a level of excellence (Puig-Samper Mulero \& Santamaría, 2007, pp. 16-22).

\section{Clinical picture and course of lathyrism}

The clinical features of lathyrism have been well known since the nineteenth century (Brissaud, 1886). The disease most frequently affects male young adults, beginning with a prodromal period characterized by nocturnal muscle cramps in the calves, urinary urgency, and a sensation of pins and needles in the legs. After a few weeks, paraparesis is established quickly, even abruptly in some cases, sometimes in association with intense motor activity. Once established, lathyrism is irreversible, although its severity varies and some clinical improvement may occur in patients with mild leg weakness following cessation of LS, especially among affected children (Spencer PS, personal observation). Poor nutrition is a probable but unproven risk factor for lathyrism, in addition to the daily amount and duration of grasspea intake. Males are more commonly and severely affected than females. In general, lathyrism is characterized by a marked increase of muscle tone in the lower limbs, bending forward of the trunk, digitigrade gait, electrophysiological findings consistent with pyramidal tract involvement, and no objective sensory or cognitive deficits (Hugon et al., 1993; Paleacu, Cohn, \& Rabey, 1999).

Motor deficits in the lower extremities of Indian cases may be extreme, with the legs extended and held in a crossed locked position ("crawler stage"), severe such that a pair of crutches is required for ambulation ("two-stick stage"), less severe ("one-stick stage"), minimal ("no-stick stage"), or detectable only on examination (subclinical stage), the range of cases forming a pyramid of disease with wheelchair-bound males at the apex (Dwivedi \& Prasad, 1964). The upper limbs remain unaffected, except for occasional increased deep tendon reflexes in those with severe spastic paraparesis (Jiménez Díaz et al., 1942; Spencer \& pp. 1-20). The appearance of degenerative changes in the spine and knees may be attributed to spasticity and altered posture (Paissos \& Demopoulos, 1982). 


\section{Atypical cases of lathyrism: the possible role of associated ergotism and different Lathyrus species}

Atypical clinical features associated with lathyrism were present among 200 survivors of the German World War II concentration camp in Wapniarka, Ukraine, who developed the disease in 1942, after approximately three months of eating a diet rich in grasspea (Kessler, 1947). Twenty-five to 30 years later, the clinical features of these patients were described by Cohn and Striefler (1981). Although some cases exhibited the usual clinical findings (Klawans, 1988, pp. 29-47), 7\% developed distal muscle atrophy and 12 patients had proprioceptive disturbances. Some $80 \%$ of the inmates were fed with a mixture of grasspea and rye, and 60 patients exhibited signs consistent with both lathyrism and ergotism, such as severe pain in their lower limbs, high blood pressure, skin necrosis, and toe amputation, as reported by Kessler, who himself had been an inmate in the concentration camp (Kessler, 360 1947; Garfinkle, Andermann, \& Shevell, 2011).

Lower-limb muscular atrophy in lathyrism may sometimes be explained by comorbid malnutrition and associated peripheral neuropathy (German, 1960; Cohn \& Striefler, 1981). Shrivastava, Bharati, and Arora (1982) demonstrated swelling and neuronal loss in anterior horn cells of the lumbar spinal cord in a patient exhibiting calf atrophy. Muscular atrophy or electrophysiological evidence of denervati n vas not observed in Spanish lathyrism patients, whose condition was clearly related to L. sauvus (Jiménez Díaz et al., 1942; Moya et al., 1967b).

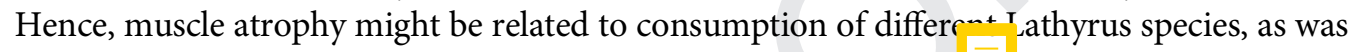
repor $^{\text {^d }}$ in Italian and Greek lathyrism patients feeding on L. cly L. cic (Marie, 1883), species with a high L- $\beta$-ODAP content, although it was not present in Q19 a large and more recent series of Greek patients (Paissios \& Demopoulos, 1962).

\section{Other neuropathological studies}

Some other historical reports of lathyrism are of limited value, as they are based on atypical clinical features (Beguiristain \& Gastaminza, 1945) or because they lack clinical data (Buzzard \& Greenfield, 1922, pp. 232-334). Striefler and colleagues (1977) described the histopathology of an Israeli patient who had developed lathyrism 35 years earlier. Findings included axonal and myelin degeneration of the pyramidal tract in the lumbar spinal cord, pallor of Goll's fasciculi, and mild atrophy of anterior horn neurons. Ultrastructural study of this case, the only one available to date, described intracytoplasmic filamentous aggregates and crystalloid inclusions of anterior horn neurons that were otherwise preserved (Hirano et al., 1976). Presumably the patient was a survivor of the Wapniarka concentration camp, so it is not possible to exclude the coexistence of both lathyrism and ergotism.

\section{Neuropathology of lathyrism: A 1944 report by Oliveras de la Riva}

Oliveras de la Riva's publication "Contribution to the Histopathology of Human Lathyrism" is a 37-page monograph with 33 illustrations. The two patients reported on had been admitted to the MNI in Barcelona in 1941. Case 2 had been the subject of a preliminary publication by neurologist Simarro Puig and pathologist Roca de Viñals, both MNI members, ${ }_{-}$willing to accept a new revision of the specimen (Simarro Puig \& Roca de Viñals, 1943). They all were well aware of Filimonov's paper (1926). 


\section{Clinical findings}

Case 1 was a 21-year-old man from Corbera de Llobregat, Barcelona province, where four other cases with lathyrism were known. He was admitted to the MNI on April 26, 1941. Five months earlier, he had begun to feed himself with 500 to 750 grams per day of grasspea along with some tomato, lettuce, and onion salads, fruit, and a ration of bread. Twice a week, he ate small amounts of meat or bacon. In February of that year, he developed muscle cramps in the calves, urinary urgency, and progressive gait difficulties. On admission, he was able to walk aided by a cane, dragging the tips of his feet. On examination, there was loss of strength in lower limbs, increased muscle tone, exaggeration of tendon reflexes, and extensor plantar responses. Three days following admission, he developed severe abdominal pain and massive hemorrhages on defecation, dying shortly afterward. The cause of death was intestinal invagination, bowel necrosis, and peritonitis.

Case 2 was a 30 -year-old man from Esparraguera, province of Barcelona, a town where numerous cases of lathyrism were known. Born in Mexico, he reportedly had "infantile paralysis" at the age of four, from which he fully recovered. From June 1940, his diet consisted of 700 grams of grasspea distributed three times a day, some vegetables and fruit, milk, and a ration of bread. In October 1940, he developed respiratory symptoms, fever, low-back pain, nocturnal calf cramps, and heavy sweating. One week later, he noticed awkwardness of his legs and difficulty initiating urination, gradually progressing over a month and a half. Upon admission to the MNI in April 1941, neurological findings consisted of leg weakness, increased muscle tone, increased patellar and ankle tendon reflexes, lower limb clonus, and extensor plantar responses. There was no evidence of muscle atrophy. In June 1941, while still in the hospital, he developed suppurative meningitis without microorganisms; he died a month and a half later. He had been treated with repeated intrathecal vitamin B1 injections.

\section{Neuropathology methods}

Both cases of lathyrism were subjected to neuropathological examination. After tissue fixation in $10 \%$ formalin, paraffin sections at multiple levels of the spinal cord, brain stem, and brain were examined. Sudan black stain was appli Herxheimer, and Kultchitzky methods. Grcu vtain was applied for axons and neurofibrils; Cajal reduced silver nitrate and Meyer thionine were used for neurons, and the Del Rio Hortega method for glia and vessels. Although microphotographs were used, Oliveras de la Riva gave preference to drawings aided by a Grail-Zeiss projection device as being more revealing. Findings were compared with normal controls, and results were arranged in seven sections according to the structures analyzed.

\section{Macroscopic findings}

With the help of a magnifying glass, transverse sections of the spinal cord of Case 1 showed a pale, triangular-shaped area located in the posterior third of the lateral columns; its outer limit was in contact with the leptomeninges and its vertex stretched to the base of posterior horns (L3 to L5 lumbar segments). Apart from inflammatory lesions due to terminal meningitis, similar changes were found in Case 2 in L3 to L5 lumbar segments, albeit greater in 
extent both in transverse sections as well as in height, reaching upward to T10-T12 segments 430 and decreasing gradually in upper levels of the spinal cord.

\section{Microscopic findings ${ }^{1}$}

\section{Myelin sheaths}

At low magnification, black Sudan staining showed numerous fatty droplets in degenerated areas that were limited to ventral lumbar spinal cord in Case 1 without reaching dorsal segments. In Case 2, lesions were also mainly located in lumbar segments but, unlike the previous case, they were visible in distal thoracic segments from T9 caudally (see Figure 3). Kultchinzky staining of degenerated areas of the spinal cord revealed marked loss of myelin fibres, as well as small foci showing swelling and deformity of myelin sheaths.

The resulting vacuolizatio sembled so-called status spongiosus, as described by French authors, and Lückeniwur, the name used by German neuropathologists. The lumbar enlargement of Case 2 showed a recent degenerating focus in the corticospinal tract on one side and an older one on the other side, with numerous axons lacking myelin sheaths (see Figure 4).

"To summarize, the essential damage in lathyrism is characterized by small degenerating myelin foci, located in the lumbar enlargement involving most of posterior and marginal areas of corticospinal tracts" (Oliveras de la Riva, 1944, pp. 314-316; see Figure 5):

Such foci tended to consolidate, extending the lumbar spinal cord in Case 1, and they involved both lumbar enlargement and lower thoracic segments in Case 2. Degeneration of other spinal cord tracts was absent in both cases. Pyramidal tract changes did not reach dorsal segments in Case 1 nor higher levels in Case 2. (Oliveras de la Riva, 1944, p. 315)

\section{a}

\section{ión.}

parición de esta pérdida de coloración en los cordor sido observada en la mielopatia funicular de la aner la forma llamada idiopática, y en la que acompaña o le otras enfermedades generales, tales como el escorbut leucemia, ictericia hemolitica, sprue, alcoholismo, ergo de Ambison, de BAsenow, diabetes, melitus, sepsis, tu Pero la distribución es diferente, apareciendo en éstas, múltiples y no bien sistematizados, destacando por su lel cordón posterior $y$ encontrándose en toda la alt hasta la decusación de la pirámides en el bulbo raqu

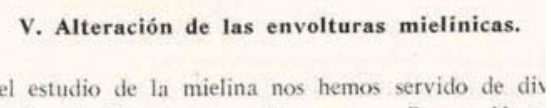

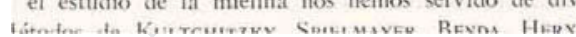

b

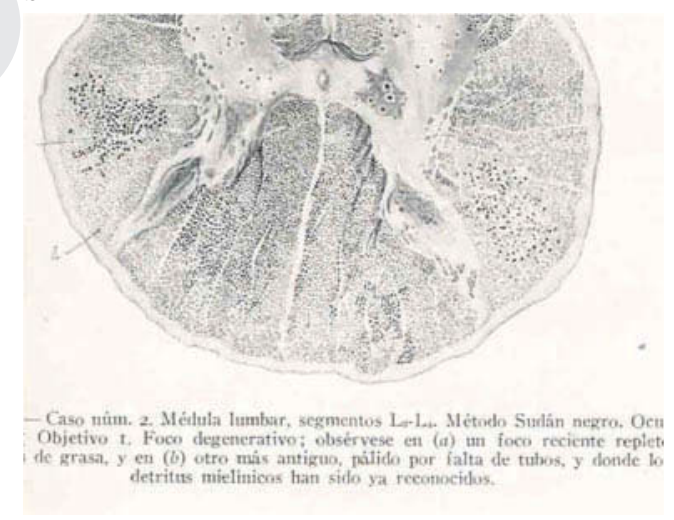

Figure 3. Lumbar spinal pathology: (a) left. Case 1. L3-L5, lumbar segments. Sudan black staining $5 \times 1$, projection; (b) right. Case 2. Lumbar spinal cord, L3-L4 segments, Sudan black staining $5 \times 1$. A recent focus of degeneration filled with lipid droplets may be seen, and an older one, with a pale appearance due to nerve tubules loss, as well as some where myelin debris has been detected. They correspond to Figures 1 and 10 in Oliveras de la Riva's 1944 publication, with their original labels.

\footnotetext{
${ }^{1}$ We have modified the order of presentation used in Oliveras de la Riva's paper (myelin, corpora amylacea, neuroglia, axons, neurons, vascular and connective tissue changes, and ependymal cells) to facilitate understanding.
} 
a

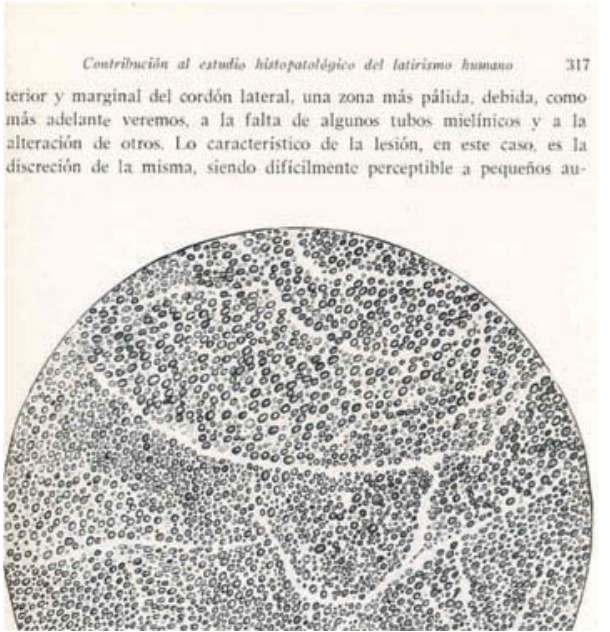

b

dones anterior $y$ posterior, en toda la altura de la misma, asi como tampoco en el tronco encefálico y en la zona de proyección motora de! centro oval.

Fin d caso núm. 1, en los segmentos correspondientes al engrosa.

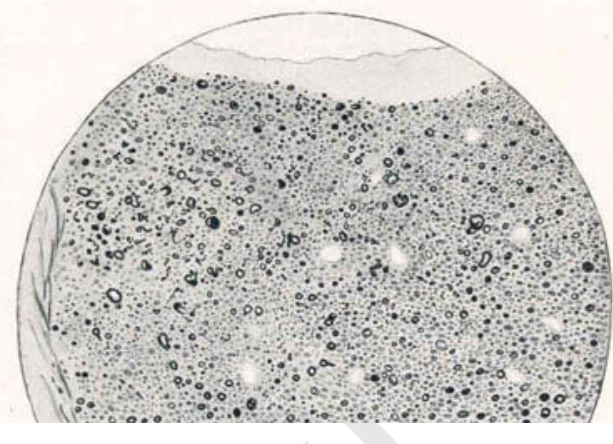

Figure 4. Lumbar spinal pathology: (a) left. normal spinal cord, Kultchitzky method; (b) right. Case 1. Lumbar segments $10 \times 20$. Loss of myelin sheaths may be seen. They correspond to Figures 4 and 3 in Oliveras de la Riva's 1944 publication, with their original labels. The corresponding text (pp. 316 and 318) reads: "We present a normal column image taken with identical magnification and technique for comparison ... with figure 3."
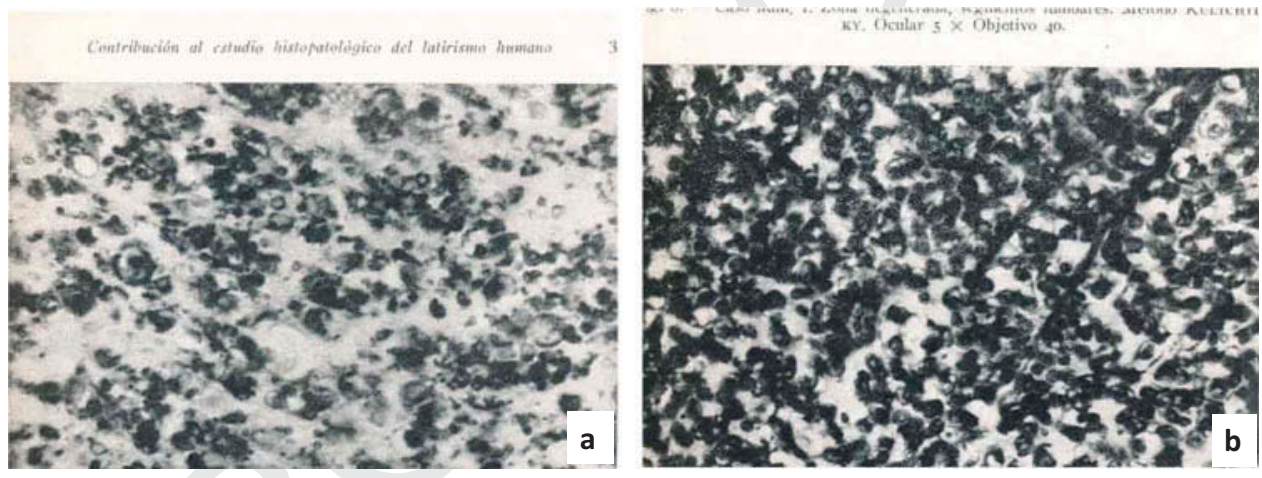

Figure 5. Lumbar spinal pathology: (a) left. "Normal [white matter] column, Kultchitzky method, $5 \times 40$ " [case and level not stated] (p. 317); (b) right. Case 1. "A degenerated area at lumbar segments, Kultchitzky method, $5 \times 40$ " (p. 318). They correspond to Figures 6 and 7 in Oliveras de la Riva's 1944 publication, with original labels. The corresponding text (p. 319) reads: "Microphotographs taken from the same area as mentioned above [lumbar segments]."

The cervical cord and medulla oblongata were spared in both cases. No changes were described in the sacral cord.

\section{Axons}

As reported, "axonal lesions are always more discrete [than myelin ones]. They consist of fragmentation and globular shaped changes, more severe in case 2, with relative preservation of fine axons. In Case 1, complete axonal fragmentation was rare" (Oliveras de la 

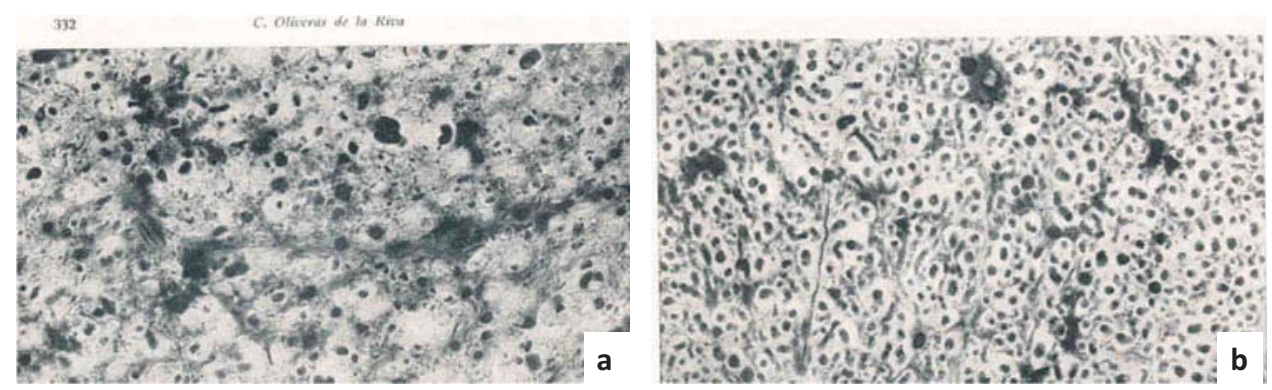

Figure 6. Lumbar spinal pathology: (a) left. Case 1. "A column area in the vicinity of a degenerative focus at lumbar level. Normal axons may be seen, as well as a mild astrocytic hypertrophic reaction" (p. 332), Gross method, $5 \times 30$; (b) right. "Case 1. A degenerating area [in the corticospinal tract] at lumbar level showing moderate axonal changes." They correspond to figures 21 and 22 in Oliveras de la Riva's 1944 publication, with their original labels. The corresponding text (p. 331) reads: "we found axonal changes in both cases ... with swelling, fragmentation and globose-shaped changes ... more marked in Case 2. In Case 1, areas with total axonal loss were rare."

Riva, 1944, pp. 331-333). Figure 6 shows axonal changes in Case 1 compared to an adjacent normal zone at the same spinal level.

\section{Neuronal changes in the grey matter in spinal cord}

Considering the symptoms of lathyrism, we were surprised to find obvious damage in spinal cord neurons in both cases. They consist of dusty appearance of perinuclear Nissl substance with thick lumps at the periphery. Large lipofuscin-filled vacuoles are seen in some areas, ... which we believe related to lathyrism toxin. (Oliveras de la Riva, 1944, p. 340)

According to Oliveras de la Riva, "preference for involvement of the posterolateral nucleus [in anterior horns] would explain muscle cramps in gastrocnemius and plantar muscles, and anterior nucleus, which innervates the external sphincter of the urethra, therefore explaining voiding difficulties" (1944, p. 343).

As indicated, Case 2 had been the subject of a preliminary publication by Simarro-Puig and 470 Roca de Viñals. As the patient was reported to have had infantile paralysis in early childhood, they underlined the absence of muscular atrophy clinically and, at postmortem, no evidence of anterior horn cell loss in lumbar spinal cord, with observations limited to the Nissl substance changes as seen in Case 1 as well (see Figure 7; "Oliveras de la Riva, 1944.).

\section{Neuroglia and connective-vasculature changes}

Glial changes depend on time elapsed since the injury. In more recent lesions, as occurred in case 1 , swollen astrocytes, disappearance of fibrillary structure and nuclear pyknosis were observed in addition to myelin degeneration. In longer-standing lesions, as in case 2, there is an intense astroglial proliferation of scarring nature, providing a markedly dense aspect to tissues, unlike the cribriform appearance of more recent lesions [as in case 1]. (Oliveras de la Riva, 1944)

These statements bear qualification. Despite the use of silver staining, cellular changes as described in Case 1 may be confusing. Swollen glial cells are presumably phagocytic microglial cells, occasionally described as amoeboid. Myelin and axonal debris are phagocytosed by these cells, which then appear with a lipid-laden, vacuolated cytoplasm, as shown by Sudan back 

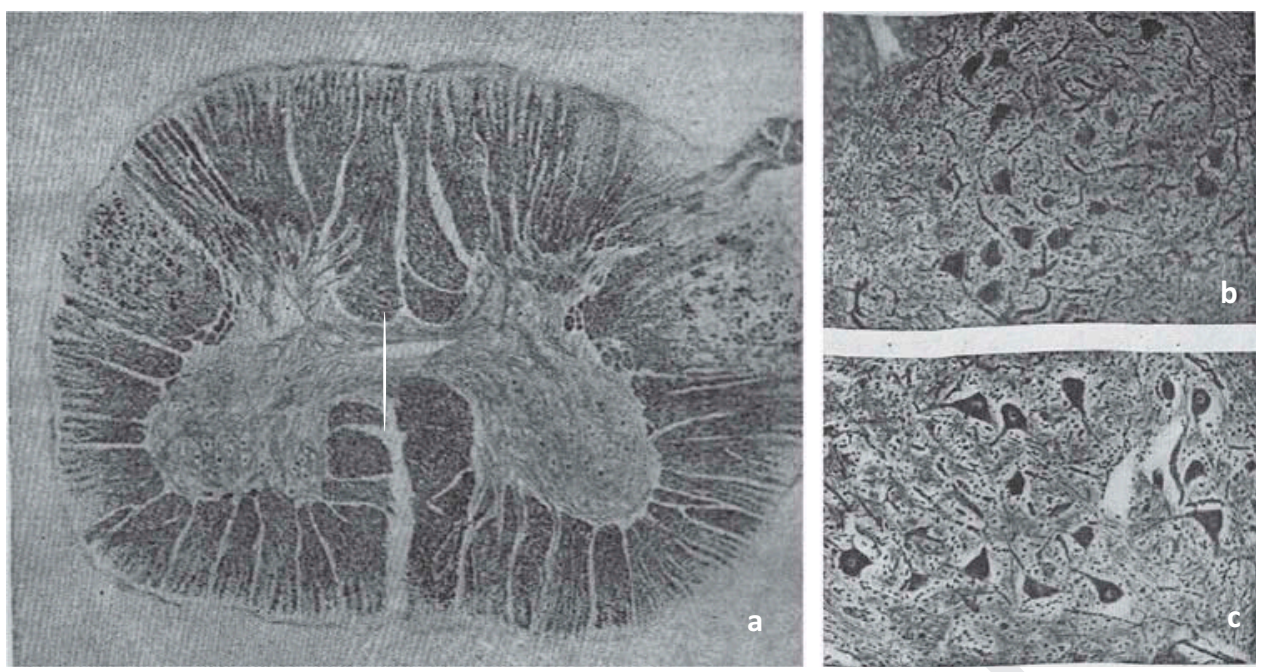

Figure 7. Lumbar spinal pathology: Illustrations from Case 2, as reported by Simarro Puig and Roca de Viñals in 1943. (a) Left. Spinal cord appearance at lumbar enlargement (Figure 12 in the original report); (b) and (c) normal anterior horn cells density at the same level (Sudan Black III stain, right and left sides; Figures 7 and 8 in the original report).

staining. Therefore, there is a clear relationship in acute lesions between myelin degeneration, 485 macrophage proliferation (from microglia) and lipid-filled vacuoles.

Regarding perivascular glia, a diffuse proliferation was observed throughout the grey matter of the spinal cord, more marked in thoracic and lumbar segments. Fibrous astrocytes formed a dense plexus around vessels, resulting in adventitial thickening of capillaries and arterioles (see Figure 8).

\section{Additional changes}

In Case 1, a proliferation of ependymal cells was noted along the entire spinal cord, leading to obliteration of the central canal. Oliveras de la Riva interpreted this as a form of congenital malformation. This should be viewed with caution, as there is a gradual obliteration of the central canal in normal subjects, in addition to wide individual variations (García-Ovejero et al., 2015). Additionally, Oliveras de la Riva observed rounded, homogeneous structures with tintorial features suggestive of corpora amylacea. These were found in degenerated areas of the spinal cord and occasionally in posterior columns. Corpora amylacea are frequently found in the spinal cord; their origin is unclear, but hemo-oxygenase-1 present in astrocytes and glucose polymer content of corpora amylacea could represent a primary glial reaction in 500 these cases (Sinadinos et al., 2014; Song et al., 2014).

\section{Primary motor cortex}

Oliveras de la Riva clearly claimed normality of primary motor cortex in both cases, assuming it unnecessary to add images. Nevertheless, the preliminary publication of Case 2 by Simarro-Puig and Roca de Viñals, who were well aware of the Filimonov's data, 505 


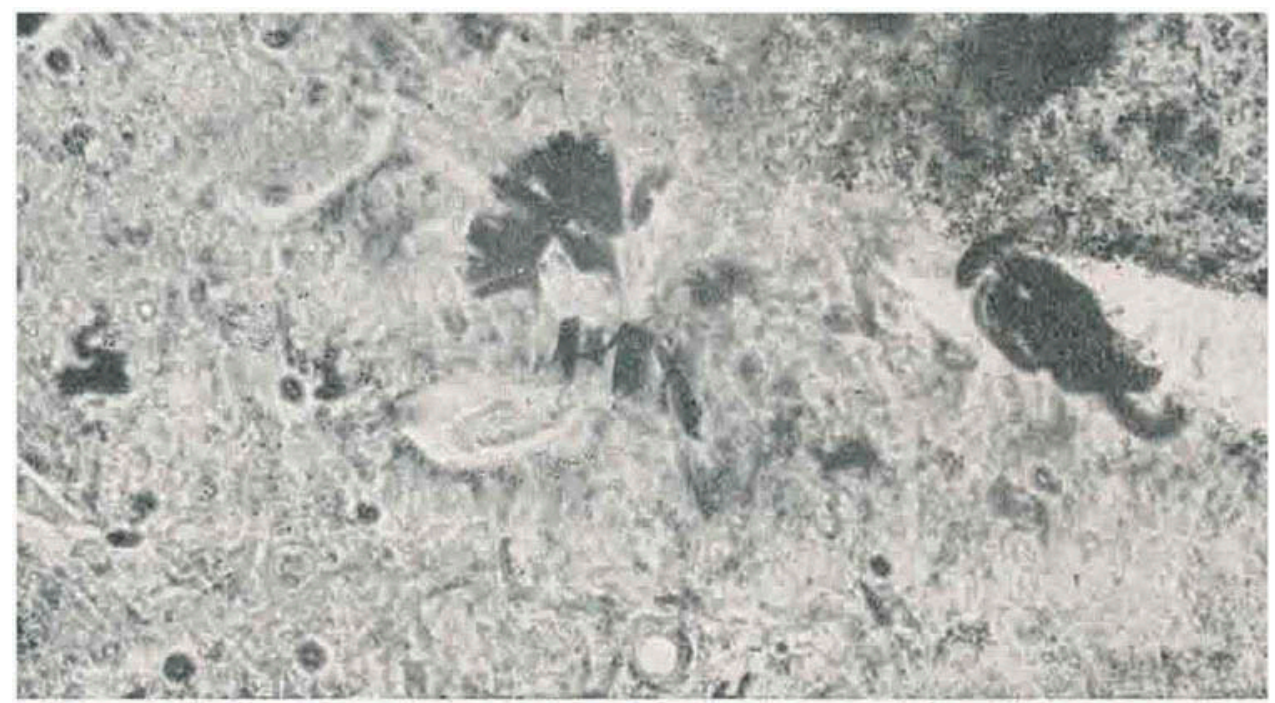

ïg. 32.-Caso núm. I. Asteriolas de la sustancia gris médulodorsal. Fmisión bras de reticulina. Método semiespecífico, para el conjuntivo, Río-Hortrois. O. lar $5 \times$ Objetivo 40 .

\section{éo-Hortega; el de Alzheimer, para vasos, y la hematoxilina fosfotún̨̧}

Figure 8. Thoracic spinal pathology: Case 1. Arteriolar vessels in grey matter at thoracic spinal cord, showing reticulin fibres. Rio-Hortega method, nearly specific for connective tissue, $5 \times 20$. This figure corresponds to Figure 32 [p. 339] in Oliveras de la Riva's 1944 publication, with their original labels. The corresponding text reads: "Perivascular scarves can be observed as shown in a microphotograph" [Figure 32, p. 340].

illustrated the normal density of Betz cells in primary motor cortex (Simarro-Puig \& Roca de Viñals, 1943).

\section{Concluding remarks}

Oliveras de la Riva (1944) summarized the essential features of his study as follows:

(1) The fundamental lesion of lathyrism consists of numerous degenerative foci in the 510 thickness of the thoracic-lumbar corticospinal tract, macroscopically appearing as a pale area.

(2) Within the degenerating foci, myelin collapse is followed later on by axonal breakdown albeit of lesser severity, giving rise to a cribriform appearance of the lesions.

(3) Neuroglia proliferation configures a scarring of old foci.

(4) Perivascular neuroglia and the adventitial layer of blood vessels undergo a process of hyperplasia and hypertrophy limited to the spinal cord. (p. 343) 


\section{Discussion}

\section{Oliveras de la Riva's contribution}

\section{Intact primary motor cortex}

In contrast to the long-held concept based on the study by Filimonov 18 years earlier, 520 Oliveras de la Riva established the preservation of Betz pyramidal cells in the primary motor cortex in his two patients, as already documented in Case 2 (Simarro-Puig \& Roca de Viñals, 1943). Additionally, Sachdev, Sachdev, and Puri (1969) studied a 16-year-old boy suffering from paralysis of the lower limbs for four years. Gross and microscopic examination of the brain revealed no abnormality. In accord with these pathological data, a recent Israeli study employing functional magnetic resonance imaging of three Ethiopian male migrants with probable lathyrism showed the expected activation of regions in the primary motor cortex following movement of the hands and feet qualitatively similar to control subjects. Moreover, tensor diffusion imaging revealed apparently normal corticospinal tracts connecting primary motor regions to the pons (Bick et al., 2016.)

\section{Spinal cord small-vessel disease and rupture of the blood-brain barrier}

Neglected aspects of lathyrism are vascular changes in spinal cord characterized as thickening of the adventitia in capillaries and arterioles associated with proliferation of perivascular fibrous astrocytes. Specifically, Oliveras de la Riva (1944, p. 340) wrote: "In both cases we could appreciate considerable adventitial thickening of capillaries and arterioles throughout the spinal cord [italics added], more marked in the grey matter and especially in vessels around the ependymal cells." Filimonov found vascular changes as well, circumscribed at the grey matter of the spinal cord, more marked in the anterior commissure and medial area of ventral horns, causing narrowing or even occlusion of the lumen of vessels. Given the long disease course of his case, he interpreted them in terms of a reparative process (Filimonov, 1926).

Oliveras de la Riva (1944) viewed small vessel changes as a response of the blood-brain barrier (BBB) to the arrival of an unknown toxin contained in grasspea. The BBB regulates the brain entry of potential neurotoxic amino acids such as L- $\beta$-ODAP (Hawkins et al., 2006). On the other hand, CNS microvasculature contains functional glutamate receptors that could respond to a flood of grasspea-derived L- $\beta$-ODAP (Kusama-Eguchi et al., 2010). Exaggerated release of excitatory aminoacids (EAA) and excessive stimulation of $\underline{N}$-methyl-D-aspartate (NMDA) receptors and other EAA receptors resulted in concentration-dependent constriction of pial microvessels (Huang et al., 1994), whereas high concentrations of glutamate and its metabolite, glutamine, caused significant concentration-dependent contractions using rings of rabbit aorta (Merritt \& Williams, 1990). Glutamate evokes the release of messengers that dilate capillaries by actively relaxing pericytes, whereas under ischaemia it evokes irreversible capillary constriction by pericytes and damage to the blood-brain barrier (Hall et al., 2014). It might thus be inferred that constant daily exposure to L- $\beta$-ODAP produces, as an early event of human lathyrism, damage to the spinal cord microvasculature with rupture of the 555 $\mathrm{BBB}$, thus allowing the entry of the neurotoxin into the CNS.

Small-vessel disease in the spinal cord may also explain patients in whom disease onset occurs over a few hours or even in a "fulminant" manner (Jiménez Díaz et al., 1942; Ludolph et al., 1987). For instance, a patient examined by one of the current authors 
Q24 (SGR) developed an irreversible paraparesis overnight while asleep (Moya et al., 1967). Strikingly, the frequency of abrupt disease at onset has varied in different epidemics. Thus, whereas only two out of 56 patients examined in Spain by Oliveras de la Riva (1941) developed paraparesis abruptly, Paissos and Demopoulos (1962) in Greece reported "sudden onset of the disease while working in the fields or while coming back home occurred in almost all" of their 97 patients (p. 238). Others have noted a relationship between excessive motor activity and symptom onset, which could be related to pyramidal stress, vascular compromise, or both. However, as microvessel changes occur along the spinal cord, the selective damage to the pyramidal tract at the thoracolumbar cord cannot be explained by a selective regional vascular leakage. It should be mentioned that clinical, neuroimaging, and pathology features of lathyrism clearly differ from spinal cord infarc- 570 tions (Weidauer et al., 2002; Masson et al., 2004).

\section{Severity of the paraparesis and foci of tissue damage}

Oliveras de la Riva (1944) described "foci" of degeneration to randomly located areas of tissue rarefaction within the pyramidal tract, assumed to be the consequence of intraspinal small vessel damage. Degenerative foci sometimes merged into larger areas at the thoracic-lumbar spinal cord, which might explain differences in the severity of paraparesis, as observed in the two patients reported (Oliveras de la Riva, 1944). This pattern differs clinically from konzo (cassavism), another form of central distal axonopathy with irreversible paraparesis of alimentary origin caused by excessive dietary dependence on root of the cyanogenic cassava plant (Manihot esculenta; see Tshala-Katumbay et al., 2002; Tshala-Katumbay \& Spencer, 2007, pp. 353-372). Patients with severe forms of konzo may develop tetraparesis or even bulbar palsy, suggesting differences of disease spread along pyramidal tracts to more proximal levels of the neuraxis (Tshala-Katumbay et al., 2011, 2013). This pattern is never found in lathyrism, irrespective of the severity of the paraparesis, either in early-onset patients (Jiménez Díaz et al., 1942) or at longterm follow up (Paissios \& Demopoulos, 1962; Moya et al., 1967; Hugon et al., 1990, pp. 49-56; 585 Hugon et al., 1993; Giménez-Roldán et al., 1994, pp. 10-25; Crone et al., 2007).

\section{Study limitations}

\section{Prodromal symptoms}

The spastic paraparesis of lathyrism is usually preceded by transient neurological complaints - such as muscle cramps, sensory complaints, or urinary urgency-which suggest involvement of different systems. This phase of the disease has been classified as Stage 1 (Buchanan, 1897): It disappears between a week and three months (Jiménez Díaz et al., 1942) to give way to an irreversible spastic paraparesis (Stage 2), unless the consumption of grasspea ceases during the prodromal stage (González Calvo \& López de Letona, 1943). In epidemics, the frequency of nocturnal muscle cramps in the calves has been reported to occur in $100 \%$ of 56 patients; frequency or urgency in micturition occurred in 94\%; and, more rarely, paraesthesiae in the legs occurred (Oliveras de la Riva, 1941).

The origin and significance of the prodromal symptoms in lathyrism remain unexplained. Muscle cramps occur in many conditions but represent a prominent complaint in motor neuron disorders such as amyotrophic lateral sclerosis, especially in early stages (Miller \& Layser, 2005; Caress et al., 2016). Oliveras de la Riva (1944) correlated them with histological changes observed in spinal cord grey matter in the form of perinuclear chromatolysis and 
peripheral clumps of Nissl substance. As it was not associated with neuronal depopulation, and given the reversible nature of the symptoms, he interpreted them as the consequence of a transient neuronal metabolic disorder. However, interpretation of the original photographs may prove difficult, as neurons in Clarke's column may appear chromatolytic under normal conditions and Nissl clumps are usually scarce and peripheral. Therefore, the neuronal changes as described are disputable. Oliveras de la Riva claimed a reduction of synaptic buttons as shown in a single neuron in the central nucleus at the anterior horn, but this should be interpreted with caution, as no images were provided showing synaptic buttons in normal controls.

\section{Nature of myelin damage}

Oliveras de la Riva's neuropathological study of two cases following a short disease course (two and eight months, respectively) depicted lathyrism as a primary demyelinating disorder focused on the corticospinal tracts of the thoracic-lumbar spinal cord. In his view, axonal degeneration would occur later and was milder in severity (Oliveras de la Riva, 1944). He hypothesized that lesions limited to the thoracolumbar segments of the spinal cord could be explained, "because this pathway [the pyramidal tract] is at a great distance from its trophic centre to explain the focal nature of tissue damage" (1944, p. 342), in agreement with current views of central-distal axonopathy.

Neuropathological case reports on lathyrism reporting underlying myelin loss in corticospinal tracts are not new. The conclusions of the frequently quoted Filimonov's article were not essentially different, as he stated, "This disorder evokes funicular myelitis, with initial degeneration of myelin fibres, starting as small pockets scattered in areas of predilection" (Filimonov, 1926, p 89). Sachdev and colleagues (1969) also emphasized demyelination as a prominent feature in their case, as well as normality of the brain. More recently, Shrivastava and colleagues (1982, p. 226) emphasized "early demyelination involving a few of the outflow tracts as an essential feature." However, the question remains whether the myelin loss represents a primary demyelinating process or, as distal axonopathy implies, is secondary to distal degeneration of corticospinal axons.

We suggest the pathology of lathyrism should be approached today according to the role of glutamate in regard to neuron-to-neuron synapse transmission not only in the grey matter as a key excitatory neurotransmitter but also in the white matter. NMDA receptor subunit GlyN1 and AMPA receptor subunit Glu A4 are colocalized with myelin, oligodendroglial cell bodies, and processes. Human white matter is vulnerable to excitotoxic events following a variety of acute insults (Christensen et al., 2016), which might include L- $\beta$-ODAP toxicity from excessive and prolonged grasspea consumption. On the other hand, ischaemia is known to cause ultrastructural damage to both axons and myelin, which may give a role to sm ili essel changes, as observed in lathyrism victims. Additionally, GluA4 receptors are colocalized with axons, often in distinct clusters (Micu et al., 2006), a possible explanation for the distribution of foci of tissue damage in the corticospinal tract, as described by Filimonov (2016) and Oliveras de la Riva (1944). Accordingly, the selective destruction of nerve fibers in the distal pyramidal tract could represent an example of "dual coup," or mixed axonal and demyelinating damage, in which axonal degeneration would be compatible with the long-held central distal axonopathy hypothesis (Thomas et al., 1984), whereas L- $\beta$-ODAP may have a direct action on oligodendrocytes/ myelin sheaths in damaged distal fibers. Because L- $\beta-$ ODAP also impacts astrocytes in cultures 
(Bridges, Hatalski, \& Shim, 1991; Miller, Nunn, \& Bridges, 1993), there is the possibility that the astrocytic response in lathyrism is not simply a response to localized neural damage.

\section{Conclusions}

To date, Oliveras de la Riva's little known report in 1944 appears to be the best study 650 available on the neuropathology of lathyrism. His extensive monograph is illustrated with numerous figures, he reported on two patients who died shortly after disease onset, and his research was performed at the prestigious Cajal neuroscience institute in Madrid. $\mathrm{He}$ applied advanced techniques available at the time, and the results were supervised by an eminent neurohistologist.

Although this study provided substantial but unappreciated advances in understanding the neuropathologylathyrism, particularly small-vessel damage and intact Betz cells in motor cortex, research using modern techniques is necessary to validate these findings. Some aspects of Oliveras de la Riva's paper are particularly controversial, notably the issue of selective myelin loss in the pyramidal tracts of the lumbar spinal cord, whether this represents a primary phenomenon or secondary to axonal fragmentation (Filimonov, 1926; Sachdev et al., 1969; Shrivastava et al., 1982), and the proposal of reversible metabolic changes in spinal cord grey matter to explain the usually reversible prodromal symptoms. Most controversial is whether lathyrism might be conceived as a spinal disease, as experimental studies in adult monkeys (Rao, 1978) and advanced imaging studies in human have led some authors to suggest (Bick et al., 2016).

The neuropathology of lathyrism requires reexamination using contemporary histological and ultrastructural methods. Given the imstances of countries where the disease is still prevalent (Woldeamanuel, Hassan, \& zurebe, 2012), we are aware of the difficulty in carrying out such studies. A multidisciplinary approach is necessary in which neuropathological assessment is just one component of the research assessment (Bolon, 2011). It would require a long-term investigation, significant investment, and the commitment of many people. We hope they might contribute to a better understanding of the disease and perhaps new avenues for prevention or even a cure.

\section{Acknowledgments}

We are indebted to the Spanish Society of Neurology Historical Museum (museo@sen.org.es) for providing important papers (Ms. Vanessa Cisteré).

\section{Funding}

This study received no external financial support.

\section{ORCID}




\section{References}

Acton HW (1922): An investigation into the causation of lathyrism in man. Indian Medical Gazette 547: 241-247.

Aguirre de Viani C (2002): Cajal y su escuela. Salamanca, Junta de Castilla y León, Consejería de 685 Educación y Cultura.

Balcells Riba M (2017): Dr. Carles Oliveras de la Riva. Aportació a l'estudi del latirismo. Neurología Catalana 32: 52-55.

Barrow MV, Simpson CF, Miller EJ (1974): Lathyrism: A review. The Quarterly Review of Biology 49: 101-128.

Beguiristain J, Gastaminza U (1945): Un caso insólito de latirismo. Revista Clínica Española 18: 317-323.

Bejr-kasem H, Sala-Padró J, Toledo M, Santamarina E, Sarriá S, González-Cuevas M, et al (2016): Epilepsia partialis continua: Aetiology, semiology, and prognosis in a Spanish adult cohort. Epileptic Disorders 18: 391-398.

Bick AS, Meiner Z, Gotkine M, Levin N (2016): Using advanced imaging methods to study neurolathyrism. Israel Medical Association Journal 18: 341-345.

Bolon B (2011): Perspectives on past practices and future trends in toxicologic neuropathology: Notes from a keynote address by Dr. Peter S. Spencer. Toxicologic Pathology 39: 15-18.

Bourlier A (1882): Le lathyrisme. Gazette Médicale de Algérie 17: 139-141.

Bridges RJ, Hatalski C, Shim SN (1991): Gliotoxic properties in the Lathyrus excitotoxic beta-N-oxalyl-L-alpha, beta-diaminopropionic acid (beta-L-ODAP). Brain Research 56: $262-268$.

Brissaud E (1886): Des Paralysies Toxiques. Paris, Asselin et Houzeau.

Bruyn GW, Poser CM (2003): Neurolathyrism. In: The History of Tropical Neurology: Nutritional Disorders. Canton, Mass., Science History Publications, pp. 89-108.

Buchanan A (1927): Report on Lathyrism in the Central Province, 1896-1902. Nagpur, India, Government Press.

Bushkovich P (2012): A Concise History of Russia. Cambridge, Cambridge University Press.

Buzzard, EF, Greenfield JG (1922): Pathology of the Nervous System. New York, Paul B. Hoeber.

Camy Sánchez-Cañete P (1945): Comentarios a las primeras observaciones de latirismo en Jaén. Medicina Clínica 4: 220-226

Cantani, A. (1873): Latirismo (Lathyrismus) illustrata da tre casi clinici. Il Morgagni 15: 745-745.

Caress JB, Ciarlone SL, Sullivan EA, Griffin, L, Cartwright, MS (2016): Natural history of muscle cramps in amyotrophic lateral sclerosis. Muscle \& Nerve 53: 513-537.

Carr R (1977): The Spanish Tragedy. The Civil War in Perspective. London, Weindenfeld and Nicolson.

Carrot E, Coulmel H (1946): Notes cliniques sur une épidémie de lathyrisme. Revue Neurologique 78: $572-580$.

Christensen PC, Samadi-Bahrami Z, Pavlov V, Stys PK, Moore GR (2016): Ionotropic glutamate 720 receptor expression in human white matter. Neuroscience Letters 630: 1-8.

Cohn DF, Striefler M (1981): Human neurolathyrism, a follow up study of 200 patients. Part I: clinical investigations. Schweizer Archiv für Neurologie, Neurochirurgie und Psychiatrie 128: 151-156.

Crone C, Petersen NT, Giménez-Roldán S, Lungholt B, Nyborg K, Nielsen JB (2007): Reduced reciprocal inhibition is seen only in spastic limbs in patients with neurolathyrism. Experimental Brain Research 181: 193-197.

Crone C, Petersen N, Nielsen JB, Giménez-Roldán S (2006): Impaired corticospinal transmission and reciprocal inhibition in the leg but not the arm in patients with neurolathyrism. Clinical Neurophysiology 117: S48.

Culebras A (1979): Chick pea and neurolathyrism. Neurology 29: 424.

Culebras M (2014): Trastornos neurológicos relacionados con la malnutrición en la Guerra Civil Española (1936-1939). Nutrición Hospitalaria 29: 712-718. 
De Castro F (2009): Towards the sensory nature of the carotid body: Hering, De Castro and Heymans. Frontiers in Neuroanatomy 3: 1-11.

De Gispert I (1976): Memòries d'un neuròleg que feu metge de batalló. Barcelona, Biblioteca Selecta, Barcelona.

Del Arco Blanco MA (2006): "Morir de hambre.” Autarquía, escasez y enfermedad en la España del primer franquismo. Revista de Historia Contemporánea 5: 241-258.

Del Cura I, Huertas R (2007): Alimentación y enfermedad en tiempos de hambre: España, 740 1937-1947. Madrid, Consejo Superior de Investigaciones Científicas.

Del Cura MI, Huertas R (2009): Describiendo el latirismo. Los clínicos ante la epidemia de latirismo en la España de la postguerra. Revista de Neurología 48: 265-270.

Desparanches T (1829): Le lathyrisme. Bulletin des Sciences Médicales. 18: 433.

Dwivedi MP, Prasad BG (1964): An epidemiological study of lathyrism in the district of Rewa: Madhya Pradesh. Indian Journal of Medical Research 58: 8-1 6

Enneking D (2011): The nutritive value of grasspea (Lathyr _utivus) and allied species, their toxicity to animals, and the role of malnutrition in neurolathyrism. Food and Chemical Toxicology 49: 694-709.

Fasanella i Seligrat A (2011): Latirisme de postguerra, 1941-1943. Gimbernat 56: 123-136.

Fernández Sanz E (1916): Dos casos de latirismo. Anales de la Real Academia Nacional de Medicina 36: $238-239$.

Fernández Sanz E (1917): Contribución a la historia del latirismo en España. Anales de la Real Academia Nacional de Medicina 37: 667-272.

Filimonov IN (1926): Zur pathologisch-anatomischen Charakteristik des Lathyrismus. Zeitschrift für die gesamte Neurologie und Psychiatrie 105: 76-92.

Freemon FR (1992): The Kozhevnikov circle: clinical Neurology in Moscow during the late nineteenth century. Journal of the History of the Neurosciences 1: 15-21.

Gallego A. (1979): Fernando de Castro. El País, September 18.

Garcia Izcara D (1918): El latirismo en los animales domésticos. Revista Veterinaria Española 12: $5-7$

García-Ovejero D, Arévalo-Martín A, Paniagua-Torija B, Florensa-Vila J, Ferrer I, Grassner L, et al. (2015): The ependymal region of the adult human spinal cord differs from other species and shows ependymoma-like features. Brain 138: 1583-1597.

Garfinkle J, Andermann F, Shevell, MI (2011): Neurolathyrism in Vapniarka: Medical heroism in a concentration camp. Canadian Journal of Neurological Sciences 38: 839-844.

German WJ (1960): Lathyrism: A review of recent developments. Journal of Neurosurgery 17: 657-663.

Giménez-Roldán S (2015): The Madrid School of Neurology (1885-1939). Revue Neurologique 171: $5-15$

Giménez-Roldán S, Ludolph AC, Hugon J, Hens M, Mateo D, Kisby GE, Spencer PS (1994). Lathyrism: Progressive central nervous system deficits more than 45 years after onset. In: Abegaz BA, Tekle-Haimanot R, Palmer VS, Spencer PS, eds., Nutrition, Neurotoxins and Lathyrism: The ODAP Challenge. New York, Third World Medical Research Foundation: pp. $10-25$. iménez-Roldán S, Spencer PS (2016): Azañón's disease. A 19th century epidemic of neurolathyrism in Spain. Revue Neurologique 172: 748-755.

González C, Conde SV, Gallego-Martín T, Olea, E. González-Obeso E, Ramírez M., et al. (2014): Fernando de Castro and the discovery of the arterial chemoreceptors. Frontiers in Neuroanatomy 8: 1-16.

González Calvo V, López de Letona A (1943): Aspectos clínicos de un nuevo foco de latirismo en Castilla. Revista Clínica Española 9: 407-411.

Grandjean, M (1895): Paralysie ataxique observée chez des kabyles à la suite de l' ingestion d' une varieté de gesses. Archives Médicaux de Pharmacologie; 1: 95.

Grashchenkov NI (1960): Relationships between British and Russian medicine and neurology, and the role of the National Hospital, Queen Square, London, in the development of Russian neuropathology. Journal of Neurology, Neurosurgery and Psychiatry 23: 185-190. 
Haileyesus, G, Mekonnen A, Tekle-Haimanot, R, Lambein F (1999): Epidemic of neurolathyrism in Ethiopia. The Lancet 354: 9175.

Hall CN, Reynell C, Gesslein B, Hamilton NB, Mishra A, Brad A., et al. (2014): Capillary pericytes 790 regulate cerebral blood flow in health and disease. Nature 508: 55-60.

Haque A, Hossain M, Wouters G, Lambein F (1996): Epidemiological study of lathyrism in northwestern districts of Bangladesh. Neuroepidemiology 15: 83-91

Hawkins, RL, O'Kane, IA. Simpson, JR. Vina JR (2016): Structure of the blood brain barrier and its role in the transport of amino acids. The Journal of Nutrition 136: 218S-226S.

Hirano A, Llena J, Striefler, M, Cohn DF (1976): Anterior horn changes in a case of neurolathyrism. Acta Neuropathologica (Berl.) 35: 277-283.

Huang QF, Gebrewold A, Zhang A, Altura BT, Altura BM (1994): Role of excitatory amino acids in regulation of rat pial microvasculature. American Journal of Physiology 266: 158-163.

Huertas R (2006): Hambre, enfermedad y locura: Aportación de Bartolomé Llopis al conocimiento de la psicosis pelagrosa. Frenia 6: 79-107.

Huertas R, Del Cura MI (2010): Deficiency neuropathy in wartime: The "paraesthetic-causalgic syndrome" described by Manuel Peraita during the Spanish Civil War. Journal of the History of the Neurosciences 19: 173-181.

Hugon J, Ludolph A, Giménez-Roldán S, Hague A, Spencer PS (1990): Electrophysiological 805 evaluation of human lathyrism-Results in Bangladesh and Spain. In: Clifford Rose F and Norris FH, eds., Amyotrophic Lateral Sclerosis and Pathogenesis: New Advances in Toxicology and Epidemiology. Japan, Smith-Gordon Co. Ltd., pp. 49-56.

Hugon J, Ludolph AC, Spencer PS, Giménez-Roldán S, Dumas JL (1993): Studies of the etiology and pathogenesis of motor neuron diseases: III. Magnetic cortical stimulation in patients with lathyrism. Acta Neurologica Scandinavica 88: 412-416.

Jiménez Díaz C (1941): Investigaciones sobre el latirismo: I. Introducción. Factores etiológicos. Revista Clínica Española 3: 303-319.

Jiménez Díaz C, De Palacios JM, Vivanco F (1950): Perplejidades en el problema etiológico del latirismo. Revista Clínica Española 36: 23-26.

Jiménez Díaz C, Ortiz de Landázuri E, Roda E (1943): Estudios sobre el latirismo.VI Comunicación. Síntesis de datos clínicos y experimentales para el conocimiento de la patogenia del latirismo. Revista Clínica Española 8: 154-166.

Jiménez Díaz C, Roda E, Ortíz de Landázuri E, Marina C, Lorente L (1942): VI Comunicación: El cuadro clínico. Revista Clínica Española 15: 168-177.

Jiménez García F, Grande Covián F (1940): Sobre los trastornos carenciales en Madrid durante la guerra. Los cuadros clínicos presentados con más frecuencia y su clasificación. Revista Clínica Española 1: 313-318.

Kessler A (1947): Lathyrismus. Monatsschrift für Psychiatrie und Neurologie 113: 345-375.

Klawans H (1988): Toscanini's Fumble. Chicago, Contemporary Books.

Kozhevnikov AY (1883): Cas de sclérose latérale amyotrophique: Dégénérescences des faciaux pyramidaux de propageant a travers tout l'encéphale. Archives de Neurologie 6: 536-576.

Kozhevnikov AY (1885): Ein Fall von lateraler amyotrophyscher Sklerose. Zentralblatt für Nervenheilkunde und Psychiatrie 18: 1-12.

Kumar S, Bejiga G, Ahmed S, Nakkoul H, Sarker A (2011): Genetic improvement of grass pea for 830 low neurotoxin ( $\beta$-ODAP) content. Food and Chemical Toxicology 49: 589-600.

Kusama-Eguchi K, Yamazaki Y, Ueda T, Suda A, Hirayama YIkegami F, et al. (2010): Hind-limb paraparesis in a rat model for neurolathyrism associated with apoptosis and an impaired vascular endothelial growth factor system in the spinal cord. Journal of Comparative Neurology 518: 928-942.

Kushchayev SV, Moskalenko VF, Wiener PC, Tsymbaliuk VI, Cherkasov VG, Dzyavulska IV, et al. (2012): The discovery of the pyramidal neurons: Vladimir Betz and a new era of neurosciences. Brain 135: 285-380

Lafuente I (1999): Tiempos de hambre: Viaje a la España de postguerra. Barcelona, Planeta D’Agostini.

Lebon J, Choussat H (1948): Une épidémie de lathyrisme in Kabilie. Presse Médicale 56: 450-451. 
Ley E, Oliveras de la Riva C (1941): Primera comunicación sobre una epidemia de latirismo. Revista Clínica Española 6: 1-30.

Llopis H (1943): Los trastornos psíquicos en la pelagra. Actas Españolas de Neurología y Psiquiatría 4: 7-31.

López Ibor JJ, Peraita M (1941): Sobre el latirismo. Actas Españolas de Neurología y Psiquiatría 1: 25-33.

Ludolph AC, Hugon J, Dwivedi MP, Schaumburg HH, Spencer PS (1987): Studies on the aetiology and pathogenesis of motor neurone disease. 1. Lathyrism: Clinical findings in established cases. Brain 110: 140-165.

Madoz P (1846-1850): Diccionario Geográfico-Estadístico-Histórico de España y sus Posesiones. Madrid [s.n.], XVI volúmenes. Establecimiento tipográfico de P. Madoz y L. Sagasti.

Mameniskiené R, Wolf P (2017). Epilepsia partialis continua: A review. Seizure 44: 74-80.

Marie P (1883): Des manifestations médullaires de l'ergotisme et du lathyrisme. Le Progrès Médical 4: $64-66$.

Masson C, Pruyo JP, Meder JF, Cordonnier C, Touzé E, de la Sayette V, et al., for the Study Group on Spinal Cord Infarction of the French Neurovascular Society (2004): Spinal cord infarction: Clinical and magnetic resonance imaging findings and short term outcome. Journal of Neurology, Neurosurgery and Psychiatry 75: 1431-1435.

Massot i Gimeno R (1942): Dos casos de latirismo. Hojas Clínicas (Reus) 13-19.

Merritt JE, Williams PB (1990): Vasospasm contributes to monosodium glutamate induced headaches. Headache 30: 575-580.

Micu I, Jiang Q, Coderre E, Ridsdale A, Zhang L, Woulfe J, et al. (2006): NMDA receptors mediate calcium accumulation in myelin during chemical ischaemia. Nature 439: 988-992.

Miller S, Nunn PB, Bridges RJ (1993): Induction of astrocyte glutamine synthetase activity by the 865 Lathyrus toxin beta-N-oxalyl-L-alpha, beta-diaminopropionic acid (beta-L-ODAP). Glia 7: 329-336.

Miller TM, Layzer RB (2005): Muscle cramps. Muscle \& Nerve 32: 431-442.

Miles M (2005): Resilience of South Asian disabling conditions: A glimpse of lathyrism among comparative histories. Lathyrus, Lathyrism Newsletter 4: 18-21.

Misra UK, Sharma VP, Singh. VP (1993): Clinical aspects of neurolathyrism in Unnao, India. Paraplegia 31: 249-254.

Moya G, Campos J, Giménez-Roldán S, Julián S, Martínez Fuertes L (1967a): Problemas epidemiológicos, médicos y sociales del latirismo a los veinticinco años de su aparición en España: Epidemia 1940-1941. Revista de Sanidad e Higiene Pública 41: 1-39.

Moya G, Campos J, Giménez-Roldán S, Julián-Ramo S, Martínez Fuertes (1967b): La spasticité du lathyrisme, spasticité de type alpha. Acta Neurologica Belga 67: 557-566

Oliveras de la Riva C (1941): Estudio Clínico-Epidemiológico del Latirismo en Cataluña. Madrid, Facultad de Medicina, tesis inéditas, Biblioteca Marqués de Valdecilla.

Oliveras de la Riva C (1944): Contribución al estudio histopatológico del latirismo humano. Trabajos del Instituto Cajal de Investigaciones Biológicas 36: 306-343.

Paissios C, Demopoulos T (1962): Human lathyrism: A clinical and skeletal study. Clinical Orthopedics 23: 236-249.

Paleacu D., Cohn, DF, Rabey TM (1999): Cognitive evaluation of patients with chronic neurolaythrism. Parkinsonism \& Related Disorders 5: 55-58.

Peña-Chocarro L, Chapata-Peña L (1999): History and traditional cultivation of Lathyrus sativus and Lathyrus cicera in the Iberian peninsula. Vegetation History and Archaeobotany 8: 49-52.

Peraita M (1946): Deficiency neuropathies observed in Madrid during the Civil War (1936-1939). British Medical Journal 2(4481): 784.

Peraita M (1949): Las Mielopatías Funiculares Carenciales (Grupo de la Pelagra). Madrid, Consejo 890 Superior de Investigaciones Científicas.

Proust A (1883): Du lathyrisme medullaire spasmodique. Bulletin de l'Academie de Médicine de Paris 12: 829-853. 
Puig-Samper Mulero MA, Santamaría A (2007). Introducción. In: Tiempos de Investigación: JAECSIC, Cien Años de Ciencia en España. Madrid, Consejo Superior de Investigaciones Científicas, 895 pp. 16-22.

Ramón y Cajal S, De Castro F (1933): Elementos de Técnica Micrográfica del Sistema Nervioso. Barcelona, Salvat Editor S.A.

Rao SLN (1978): Entry of $\beta$-N-oxalyl-L- $\alpha-\beta$-diaminopropionic acid, the Lathyrus sativus neurotoxin into the central nervous system of the adult rat, chick and the rhesus monkey. Journal of 900 Neurochemistry 30: 1467-1470.

Richter J (2007): Pantheon of brains: The Moskow Brain Research Institute 1925-1936. Journal of the History of the Neurosciences 16: 138-149.

Rodríguez Arias B (1950): Estudio de una epidemia de latirismo en España. Medicina Clínica 15: 370-374.

Rodríguez Arias B (1969): La pequeña crónica, en glosa, de un hospital barcelonés: Instituto Neurológico Municipal. Anales de Medicina y Cirugía 45: 419-426.

Rossolimo GI (1891): Recherches expérimentales sur les vois motrices de la moelle épiniere. Archives de Neurologie (Paris) 22: 52-69, 189-203.

Rossolimo GI (1902): Le reflex profond du gross orteil. Le réflex profond du gross orteil. Revue Neurologique 10: 723-724.

Sachdev, JC, Sachdev D, Puri D (1969): Morphological study in a case of lathyrism. Journal of the Indian Medical Association 52: 320-322.

Sala Ginabreda JM, De Gispert Cruz I (1943): Latirismo infantil. Actas Españolas de Neurología y Psiquiatría 11: 86-89.

San Martín A (1873): Enfermedad de Azañón. El Siglo Médico 20: 82-86.

Satran RGI (2007): Rossolimo (1860-1928) neurologist and public benefactor. Journal of the History of the Neurosciences 16: 65-73.

Selye H (1957): Lathyrism. Revue Canadien de Biolologie 16: 1-82.

Shrivastava KK, Bharati RS, Arora MM (1982): Rare postmortem findings in a case of human lathyrism. Indian Journal of Pathology and Microbiology 25: 225-228.

Shterenshis M, Vaiman M (2007): European influences on Russian neurology in the eighteenth and nineteenth centuries. Journal of the History of the Neurosciences 16: 6-18.

Simarro Puig J, Roca de Viñals R(1943): Aportación a la anatomía patológica del latirismo (una observación anatomoclínica). Revista Clínica Española 8: 107-112.

Singh SS, Rao SLN (2013): Lessons from neurolathyrism: A disease of the past \& the future of Lathyrus sativus (Khesari dal). Indian Journal of Medical Research 138: 32-37.

Sinadinos C, Valles-Ortega J, Boulan L, Solsona E, Tevy MF, Marquez M, et al. (2014): Neuronal glycogen synthesis contributes to physiological aging. Aging Cell 13: 935-945.

Sleeman WH (1844): Rambles and Recollections of an Indian Official, Vol. 1. London, Hatchard \& Sons.

Solé-Llenas J (1998): El Instituto Neurológico Municipal de Barcelona: Notas Históricas. Barcelona, Montcada i Reixach, Gráficas Rimont.

Song W, Zukor H, Liberman A, Kaduri S, Arvanitakis Z, Bennett DA, et al. (2014): Astroglial heme oxygenase-1 and the origin of corpora amylacea in aging and degenerating neural tissues. Experimental Neurology 254: 78-89.

Spencer PS (1995): Lathyrism. In: Vinken PJ, Bruyn GW, Klawans HL, eds., Handbook of Clinical Neurology, Part 2, Vol. 21. Amsterdam: Elsevier Science Publishers, pp. 1-20.

Spencer PS, Ludolph A, Dwivedi MP, Roy D, Hugon J, Schaumburg HH (1986): Lathyrism: Evidence for role of the neuroexcitatory aminoacid BOAA. The Lancet 328: 1066-1067.

Spencer PS, Schaumburg HH (1983): Lathyrism: A neurotoxic disease. Neurobehavioral Toxicology and Teratology 5: 625-629.

Spencer PS, Schaumburg HH, Cohn DF, Seth PK (1984): Lathyrism: A useful model of primary lateral sclerosis. In: Rose FC, ed., Research Progress in Motor Neuron Disease. London, Pitman Medical Publishers, pp. 312-327.

Stockman R (1917): Lathyrism. Edinburgh Medical Journal 19: 277-296. 
Striefler M, Cohn DF, Hirano A, Schujman E (1977): The central nervous system in a case of neurolathyrism. Neurology 127: 1176-1178.

Thomas H (1977): The Spanish Civil War (3rd ed.). London, Hamish Hamilton.

Thomas PK, Schaumburg HH, Spencer PS, Kaeser HE, Pallis KR, Clifford Rose F, Wadia NH (1984): Central distal axonopathy syndromes: Newly recognized models of naturally occurring human degenerative disease. Annals of Neurology 15: 313-315.

Tshala-Katumbay N, Mumba L, Okitundu K, Kazadi Banea T, Tyllleskär T, et al. (2013): Cassava food toxins, konzo disease, and neurodegeneration in sub-Sahara Africans. Neurology 80: 955 949-951.

Tshala-Katumbay N, Olofsson KE, Kazadi-Kayembe T, Tylleskär T, Fällmar P (2002): Analysis of motor pathway involvement in Konzo using transcranial electrical and magnetic stimulation. Muscle \& Nerve 25: 230-235.

Tshala-Katumbay DD, Spencer PS (2007): Toxic disorders of the upper motor neuron system. 960 In: Eisen A, Shaw P, eds., Handbook of Clinical Neurology, Vol. 82. New York, Elsevier, pp. 353-372.

Valko P, Bassetti CL (2006): Aleksej Yakovlevich Kozhevnijov (1836-1902). Journal of Neurology 253: $537-538$.

Vein AA (2007): Introduction. Journal of the History of the Neurosciences 16: 2-5.

Vein AA, Maat-Schieman MLC (2008): Famous Russian brains: Historical attempts to understand intelligence. Brain 131: 583-590.

Wadia NH (2005): Neurological Practice, an Indian Perspective. New Delhi, Elsevier.

Weidauer S, Nichtweiss M, Lanfermann H, Zanella FE (2002): Spinal cord infarction: MR imaging and clinical features in 16 cases. Neuroradiology 44: 851-857.

Woldeamanuel YW, Hassan A, Zenebe G (2012): Neurolathyrism: Two Ethiopian case reports and review of the literature. Journal of Neurology 259: 1263-1268. 